Article

\title{
Oxidative Coupling of Methane over YSZ Support Catalysts for Application in $\mathrm{C}_{2}$ Hydrocarbon Production
}

\author{
Kridsada Khammona ${ }^{1}$, Wisitsree Wiyaratn ${ }^{2} *$, Weerinda Appamana ${ }^{1}$, \\ and Suttichai Assabumrungrat ${ }^{1}$
}

1 Centre of Excellence in Catalysis and Catalytic Reaction Engineering, Department of Chemical Engineering, Faculty of Engineering, Chulalongkorn University, Bangkok 10330, Thailand 2 Faculty of Industrial Education and Technology, King Mongkut's University of Technology Thonburi, Bangkok 10140, Thailand

*E-mail: Wisitsree.wiy@kmutt.ac.th (Corresponding author)

\begin{abstract}
This paper studies the development of $\mathrm{Mn}_{-} \mathrm{Na}_{2} \mathrm{WO}_{4}$ catalysts on YSZ support for oxidative coupling of methane reaction. It can be divided into two parts; (1) study in fixed bed reactor (FBR), and (2) study in solid oxide fuel cell reactor (SOFC). In part I, the experiments were performed using co-feeds of methane, oxygen and nitrogen inert gas at a ratio of 4:1:5 for different temperatures $(973-1173 \mathrm{~K})$. Mn- $\mathrm{Na}_{2} \mathrm{WO}_{4}$ catalyst on YSZ support was doped with sulfur, phosphorous, and cerium in order to improve its catalytic reactivity. The results indicated that sulfur and phosphorous showed the good improvement for $\mathrm{Mn}-\mathrm{Na}_{2} \mathrm{WO}_{4}$ catalyst on YSZ support. At $1073 \mathrm{~K}, \mathrm{~S}-\mathrm{Mn}_{-}-\mathrm{Na}_{2} \mathrm{WO}_{4} / \mathrm{YSZ}$ provided $\mathrm{C}_{2}$ selectivity of $60.3 \%$ and methane conversion of $31.1 \%$, while $\mathrm{P}-\mathrm{Mn}$ $\mathrm{Na}_{2} \mathrm{WO}_{4} / \mathrm{YSZ}$ offered $\mathrm{C} 2$ selectivity of $59.8 \%$ and methane conversion of $34.1 \%$. P-Mn$\mathrm{Na}_{2} \mathrm{WO}_{4} / \mathrm{YSZ}$ catalyst was selected as anode catalysts for further study in the SOFC reactor. The experiments were carried out using $\mathrm{La}_{0.8} \mathrm{Sr}_{0.2} \mathrm{MnO}_{3}$ (LSM) as the cathode catalyst, $8 \mathrm{~mol} \%$ yttria-stabilized zirconia (YSZ) as the electrolyte. P-Mn- $\mathrm{Na}_{2} \mathrm{WO}_{4} / \mathrm{YSZ}$ exhibited the best performance, providing $\mathrm{C}_{2} \mathrm{H}_{4}$ selectivity of $89.0 \%$, methane conversion of $10.5 \%$ and maximum power density of $7.2 \mathrm{~W} / \mathrm{m}^{2}$ at $1123 \mathrm{~K}$. In addition, the stability of the P-Mn- $\mathrm{Na}_{2} \mathrm{WO}_{4} / \mathrm{YSZ}$ catalyst was tested at $1123 \mathrm{~K}$. Good stability of the reaction system could be observed at least for 29 hours.
\end{abstract}

Keywords: OCM, $\mathrm{C}_{2}$ hydrocarbon, electro co-generation, YSZ.

ENGINEERING JOURNAL Volume 19 Issue 4

Received 25 October 2013

Accepted 7 January 2015

Published 31 July 2015

Online at http://www.engj.org/

DOI:10.4186/ej.2015.19.4.1 


\section{Introduction}

Solid oxide fuel cell is an electrochemical cell that converts chemical energy of a fuel into electrical energy with water and heat as its by-products [1,2]. It has a number of advantages particularly its high efficiency and low emission of pollutants [3-5]. Although in conventional operation, the main objective of SOFC is to generate electricity, some researchers have focused on the application of SOFC as a multifunctional reactor for co-generation of chemicals and electrical power [6-10]. Various valuable industrial compounds such as ethylene, hydrogen, hydrogen cyanide, nitric oxide, styrene, and formaldehyde have been considered to Alcaide et al [11]. In this study, the focus is on the production of ethylene as it is one of the most important feedstock in the petrochemical industry. Oxidative coupling of methane (OCM) becomes an interesting route for ethylene production as it requires only one reaction step unlike the conventional route via production of synthesis gas (carbon monoxide and hydrogen) which requires many steps. The concept of chemicals and electrical power co-generation in SOFC reactor can be applied to this OCM reaction. In the past two decades, researchers have attempted to develop active and selective catalysts as well as to understand reaction mechanisms. In SOFC reactor, White et al. (1992) [12] investigated anode for solid oxide fuel cells to generated $\mathrm{C}_{2}$ hydrocarbon included $\mathrm{Sm}_{0.5} \mathrm{Ce}_{0.5} \mathrm{CuO}_{3}, \mathrm{~Tb}_{0.8} \mathrm{Sm}_{0.2} \mathrm{CuO}_{3}$, $\mathrm{Gd}_{0.9} \mathrm{Th}_{0.1} \mathrm{CuO}_{3}, \quad \mathrm{Gd}_{0.9} \mathrm{Na}_{0.1} \mathrm{MnO}_{3}$ and $\mathrm{Th}_{0.8} \mathrm{Yb}_{0.2} \mathrm{NiO}_{3}$. The cell was $\mathrm{CH}_{4}$, (anode) electrocatalyst $/ \mathrm{ZrO}_{2}\left(8 \% \mathrm{Y}_{2} \mathrm{O}_{3}\right) / \mathrm{La}_{0.9} \mathrm{Sr}_{0.1} \mathrm{MnO}_{3}, \mathrm{O}_{2}$ (air). The experiment result shows almost anode catalyst exhibit high $\mathrm{C}_{2}$ selectivity more than $70 \%$ but provides low conversion. Moreover, Tagawa et al. (1999) studied in a membrane reactor for OCM reaction for a tube type cell unit (LSM/YSZ/LaA1O) and showed low yield only 7-8\% [13]. Thus in this study we studied YSZ support for sodium tungsten manganese catalyst which these supports active and selective with OCM reaction. YSZ supports have the thermal expansion nearby YSZ electrolyte to avoid cracking during the cell operation and selective with OCM reaction; thus we interest to apply to anode support catalyst for SOFC and preliminary research investigated in fixed bed reactor. In addition, applied YSZ support to anode catalyst can reduce thickness of electrolyte impact to high oxygen permeate to anode side lead to increase reaction rate. Therefore, in this work, the OCM over $\mathrm{Mn}-\mathrm{Na}_{2} \mathrm{WO}_{4}$ with YSZ support to produce $\mathrm{C} 2$ hydrocarbon in a fixed bed reactor and to produce simultaneously $\mathrm{C}_{2}$ hydrocarbon and electrical power for SOFC typed reactor are investigated.

\section{Experimental}

\subsection{Catalyst Preparation and Characterization}

The $5 \% \mathrm{Na}_{2} \mathrm{WO}_{4}-2 \% \mathrm{Mn} / \mathrm{YSZ}$ catalysts were prepared by the incipient wetness impregnation method following the method described in literature of Wang et al. [14]. The YSZ support was first impregnated with an aqueous solution of $\mathrm{Mn}\left(\mathrm{NO}_{3}\right)_{2}$, and then dried for $10 \mathrm{~h}$ at room temperature. After that it was dried at $373 \mathrm{~K}$ overnight. Next the impregnation method was repeated using an aqueous solution containing an appropriate amount of $\mathrm{Na}_{2} \mathrm{WO}_{4}$. The $2 \mathrm{wt} \% \mathrm{~S}, 2 \mathrm{wt} \% \mathrm{P}$ and $2 \mathrm{wt} \%$ Ce were added into the catalyst by the incipient wetness impregnation method after impregnating $\mathrm{Na}_{2} \mathrm{WO}_{4}$. Finally, the catalysts were calcined in air for $5 \mathrm{~h}$ at $1123 \mathrm{~K}$.

The synthesized catalysts were determined their physical properties by various techniques. Surface area and pore size were determined by BET method. The crystalline phases of prepared samples were identified by $\mathrm{x}$-ray diffraction technique using $\mathrm{Cu}-\mathrm{K} \alpha$ radiation. The $\mathrm{x}$-ray diffractograms were recorded in range of $10^{\circ}$ to $80^{\circ}(2 \Theta)$. Scanning Electron Microscopy (SEM) was also used to examine the surface morphology of synthesized catalyst.

\subsection{Catalytic Activity Testing}

\subsection{1. $\quad$ Fixed bed reactor}

Activity tests were carried out in a quartz fixed-bed microreactor (i.d. $6 \mathrm{~mm}$ ), using $0.2 \mathrm{~g}$ of catalyst as shown in Fig. 1. A thermocouple was attached in the inside wall of the reactor to monitor the reactor temperature and to control the furnace. The catalyst bed was heated to a desired temperature (973-1173 K) under nitrogen flow $25 \mathrm{ml} \cdot \mathrm{min}^{-1}$ and $1 \mathrm{~atm}$. The reactant consists of methane, oxygen and nitrogen at a 
ratio of 4:1:5. Then the samples were analyzed by a TCD gas chromatograph (Shimadzu GC8A) to determine the product concentrations using a PorapakQ column for the separation of $\mathrm{CH}_{4}, \mathrm{CO}_{2}, \mathrm{C}_{2} \mathrm{H}_{4}$, and $\mathrm{C}_{2} \mathrm{H}_{6}$, and a $5 \AA$ molecular sieve column for the separation of $\mathrm{O}_{2}, \mathrm{CH}_{4}$, and $\mathrm{CO}$.

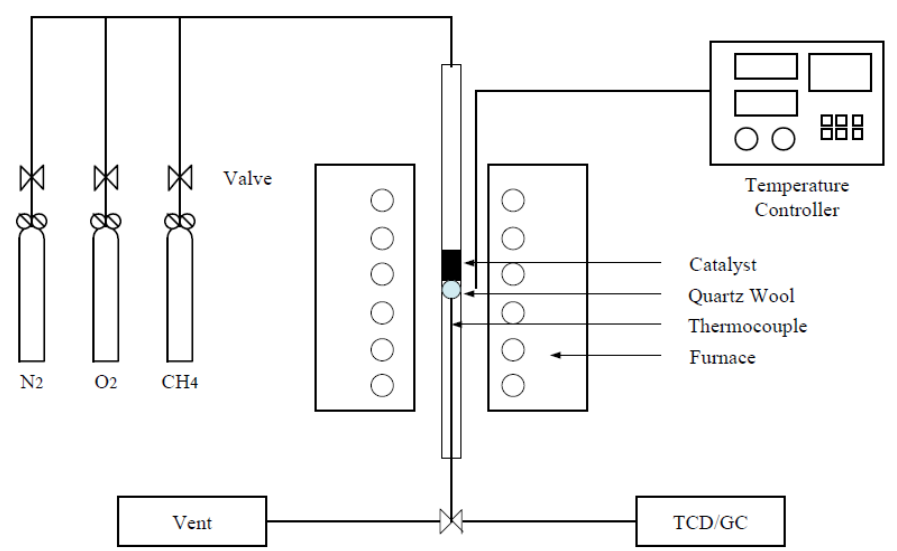

Fig. 1. Schematic diagram of oxidative coupling of methane in fixed bed.

The supplied gases were composed of nitrogen, methane, and oxygen. For each gas cylinder, the pressure regulator was installed at the outlet in order to set pressure to the valve controller. The valve controllers were installed for adjusting the flow rate of inlet gases.

\subsubsection{SOFC reactor}

\subsubsection{Apparatus}

The schematic diagram of the SOFC reactor was illustrated in Fig. 2. A tube-type YSZ membrane $(8 \mathrm{~mol} \%$ $\mathrm{Y}_{2} \mathrm{O}_{3}$, thickness $=1.5 \mathrm{~mm}$, inside diameter $=18 \mathrm{~mm}$, outside diameter $=21 \mathrm{~mm}$, length $100 \mathrm{~mm}$, effective surface area is $0.006126 \mathrm{~m}^{2}$ ) was used as an electrolyte. The anode catalyst on the inner surface of the tube while $\mathrm{La}_{0.85} \mathrm{Sr}_{0.15} \mathrm{MnO}_{3}$ (abbreviated as LSM) prepared by a conventional paste method on the outer side was used as the cathode. Platinum wire has diameter size $0.5 \mathrm{~mm}$, which was connected with cathode and anode side for measure the current by multi-meter. The reactor was heated to a desired temperature (973$1273 \mathrm{~K}$ ) under argon flow $50 \mathrm{ml} \cdot \mathrm{min}^{-1}$ at anode side and oxygen was allowed to continually flow into the cathode catalyst at a total flow rate $100 \mathrm{ml} \cdot \mathrm{min}^{-1}$ at $1 \mathrm{~atm}$. At $973 \mathrm{~K}$ the argon was transposed to methane continually flow into anode catalyst side at total flow rate $5 \mathrm{ml}^{-\mathrm{min}^{-1}}$. Then the samples were analyzed by a TCD gas chromatograph (Shimadzu GC8A) to determine the product concentrations using a PorapakQ column for the separation of $\mathrm{CH}_{4}, \mathrm{CO}_{2}, \mathrm{C}_{2} \mathrm{H}_{4}$, and $\mathrm{C}_{2} \mathrm{H}_{6}$, and a $5 \AA$ molecular sieve column for the separation of $\mathrm{O}_{2}, \mathrm{CH}_{4}$, and $\mathrm{CO}$. 


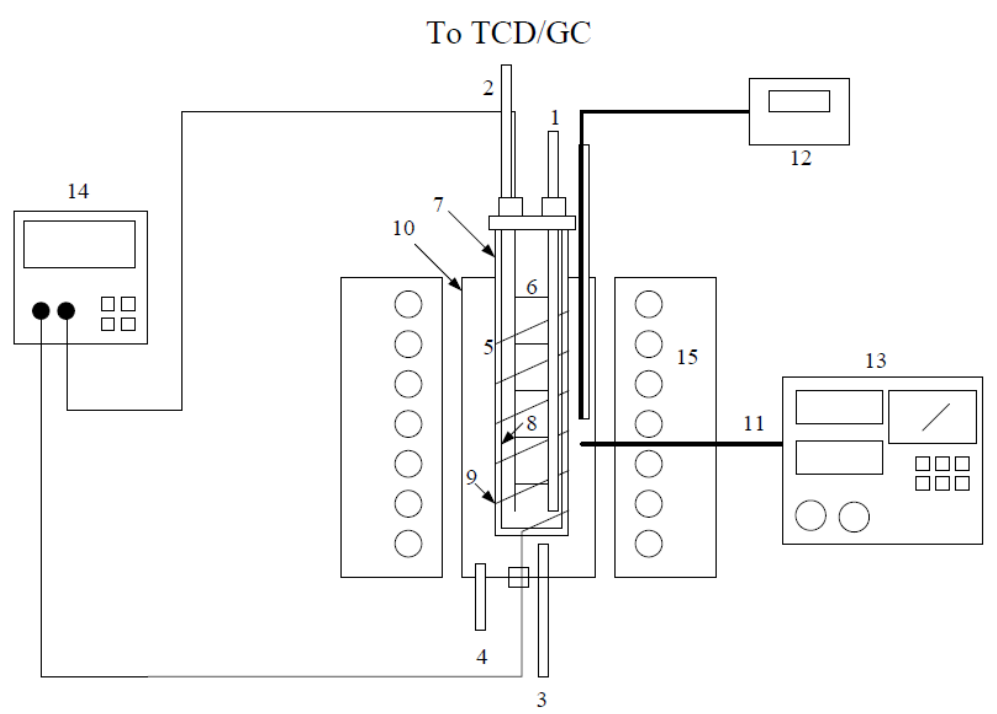

Fig. 2. Schematic diagram of oxidative coupling of methane in SOFC reactor.

2.2.2.2. Anode and cathode preparation

The anode catalyst was prepared on the inside of YSZ tube by the paste method. The $1.0 \mathrm{~g}$ catalyst powder was mixed with grycerol and pasted into film on the inside of YSZ tube and heated at $1123 \mathrm{~K}$ for about 3 hrs in air.

The $0.2 \mathrm{~g}$ LSM powder was mixed with grycerol and pasted into film on the outside of YSZ tube and heated at $1123 \mathrm{~K}$ for about $3 \mathrm{~h}$ in air.

\section{Result and Discussion}

\subsection{Catalyst Characteristics}

The YSZ support in XRD pattern involve in part metal loading, which did not found active phase such as $\mathrm{Na}_{2} \mathrm{WO}_{4}\left(17^{\circ}\right), \mathrm{Na}_{2} \mathrm{~W}_{2} \mathrm{O}_{7}\left(15.5^{\circ}\right), \mathrm{Na}_{2} \mathrm{SO}_{4}\left(34^{\circ}, 49^{\circ}\right)$ but found only $\mathrm{Mn}_{2} \mathrm{O}_{3}\left(33^{\circ}\right)$ in catalyst promoted with manganese except $\mathrm{S}-\mathrm{Na}_{2} \mathrm{WO}_{4}-\mathrm{Mn} / \mathrm{Y}_{2} \mathrm{O}_{3}$ and $\mathrm{S}-\mathrm{Na}_{2} \mathrm{WO}_{4}-\mathrm{Mn} / \mathrm{YSZ}$. Figure 3 shows that the diffraction peaks were unexpanded and remained unchanged this cause may be the formation of the composite oxide $\mathrm{Na}_{2} \mathrm{WO}_{4}, \mathrm{Na}_{2} \mathrm{~W}_{2} \mathrm{O}_{7}, \mathrm{Na}_{2} \mathrm{SO}_{4}, \mathrm{Mn}_{2} \mathrm{O}_{3}$ as an amorphous phase as described by $\mathrm{Li}$ and Wang [15].

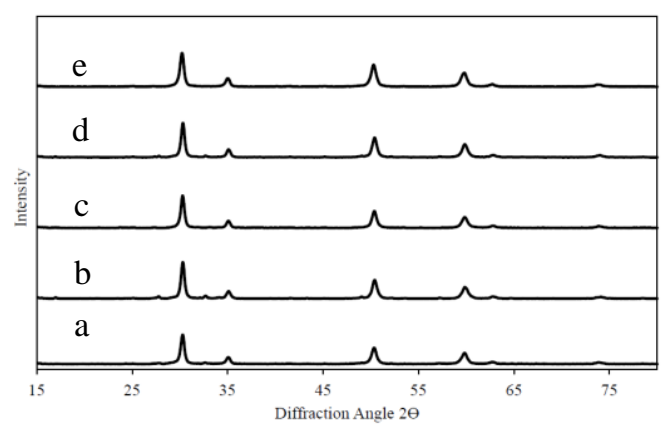

Fig. 3. The XRD pattern a) YSZ, (b) $\mathrm{Na}_{2} \mathrm{WO}_{4}-\mathrm{Mn} / \mathrm{YSZ}$, (c) S-Na2 $\mathrm{WO}_{4}-\mathrm{Mn} / \mathrm{YSZ}$, (d) $\mathrm{P}-\mathrm{Na}_{2} \mathrm{WO}_{4}$

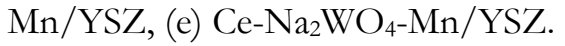

Scanning electron microscopy (SEM) and energy dispersive $\mathrm{x}$-ray spectroscopy (EDS) techniques were carried out over the catalysts. The Na, W, Mn, S, P, Ce, La, Sr, Mn, Zr, and O elements detected by EDS technique, and the amount of elements on all supports approximated with theoretical values. In additional the dispersion of elements was good that observed in SEM-EDS elemental mapping. In all the SEM micrographs, the particles with uniform size can be observed together with aggregated clusters consisting of 
many particles, as shown in Figs. 4-8. However the all SEM micrographs did not show the difference between metal oxide and support.

From mapping of element on YSZ support catalyst it found dispersion of each element on surface support. The contents of $\mathrm{Na}, \mathrm{W}$, and $\mathrm{Mn}$ in the catalyst between $0.51-3.65 \%, 3.15-9.02 \%$, and $1.55-5.69 \%$, respectively, which was similar with Ji, et. al. [16]. They reported high performance of $\mathrm{Na}_{2} \mathrm{WO}_{4}-\mathrm{Mn} / \mathrm{SiO}_{2}$ consist of the content $0.4-2.3 \% \mathrm{Na}, 2.2-8.9 \% \mathrm{~W}$, and $0.5-3.0 \% \mathrm{Mn}$. In other the percent content element did not far from theoretical.
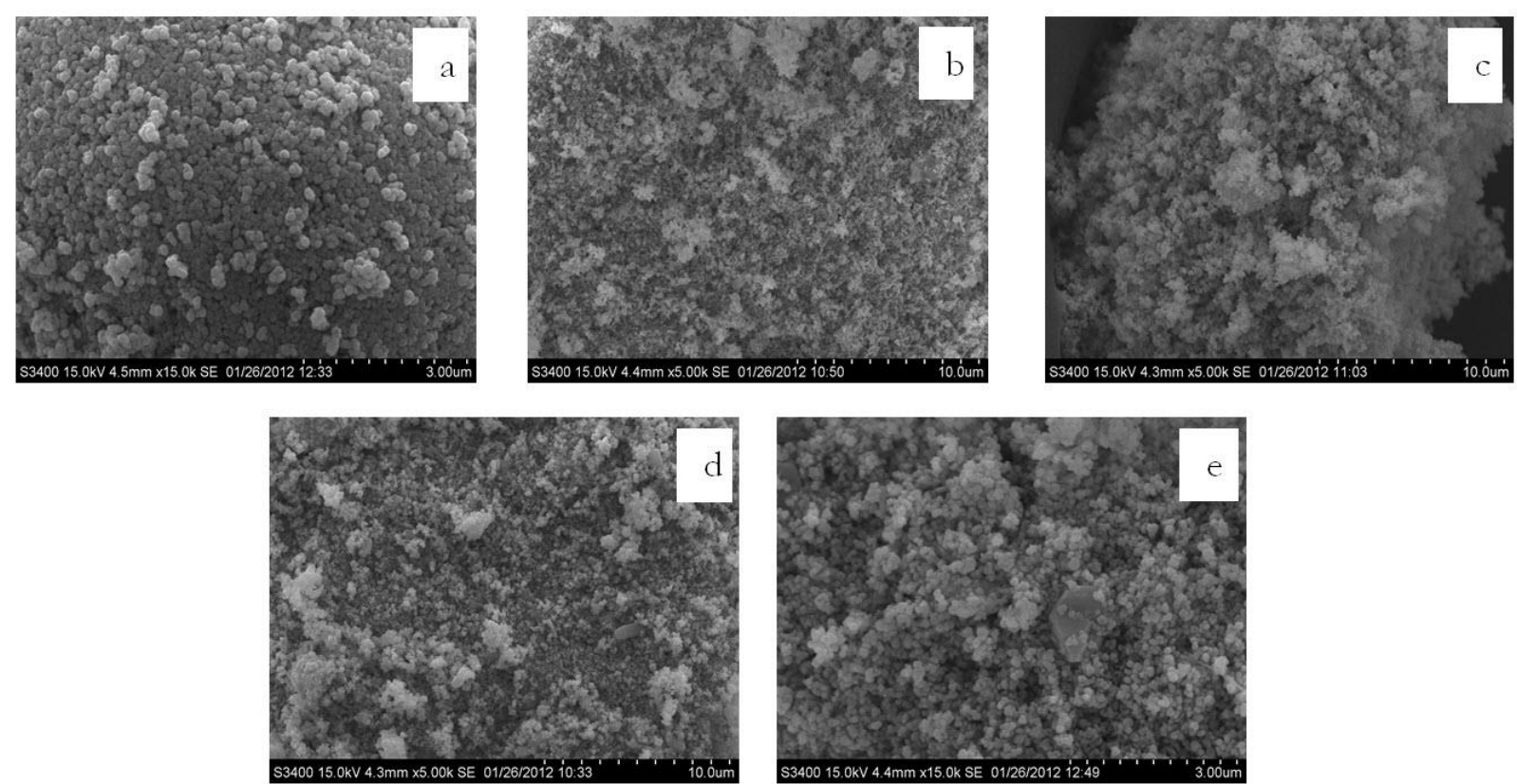

Fig. 4. Surface morphology of catalyst on YSZ support a) YSZ, (b) $\mathrm{Na}_{2} \mathrm{WO}_{4}-\mathrm{Mn} / \mathrm{YSZ}$, (c) S-Na2 $\mathrm{WO}_{4}$

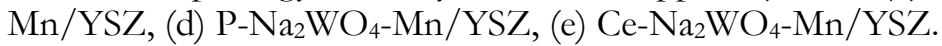
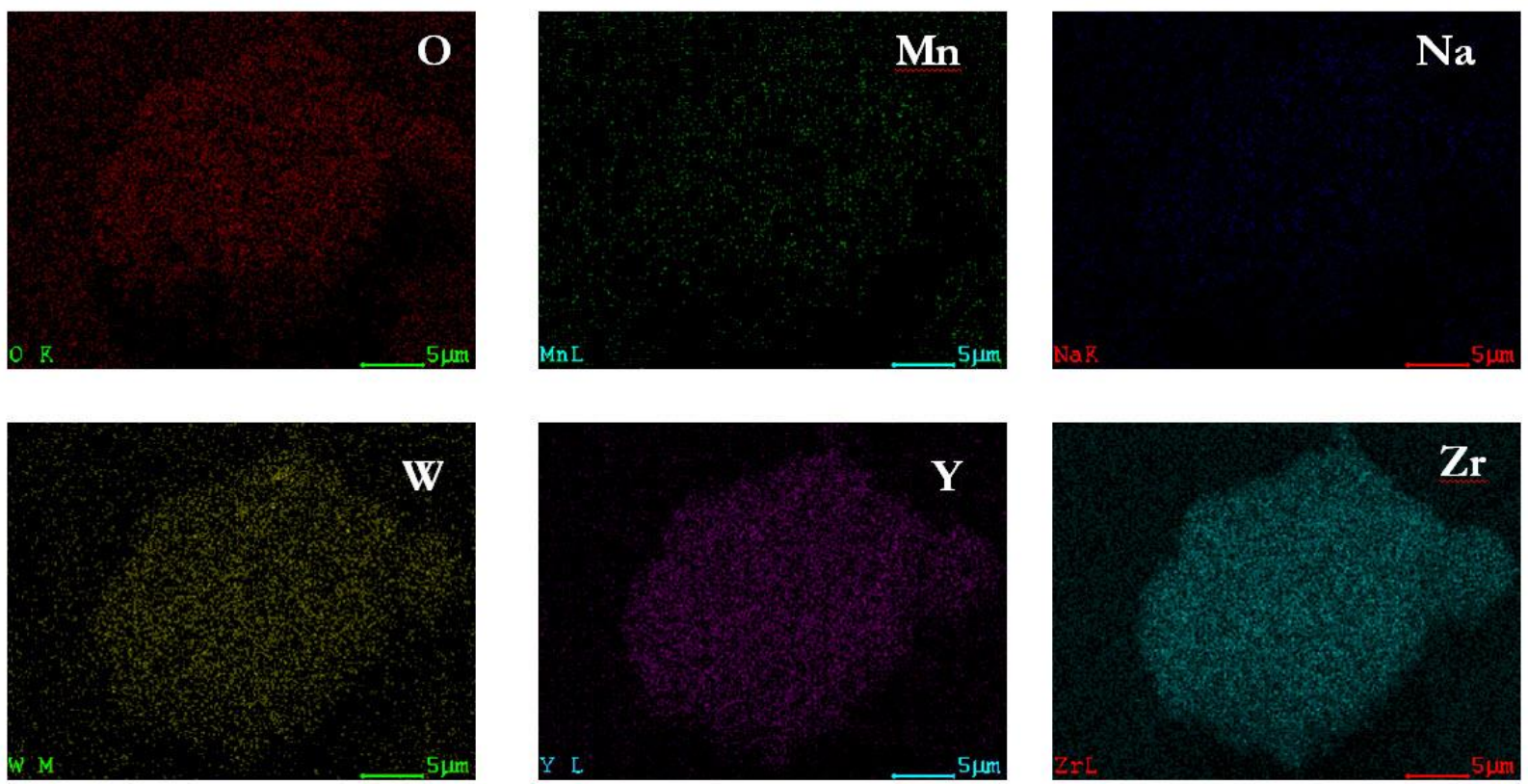

Fig. 5. The SEM-EDS mapping of elements on $\mathrm{Na}_{2} \mathrm{WO}_{4}-\mathrm{Mn} / \mathrm{YSZ}$ catalyst. 

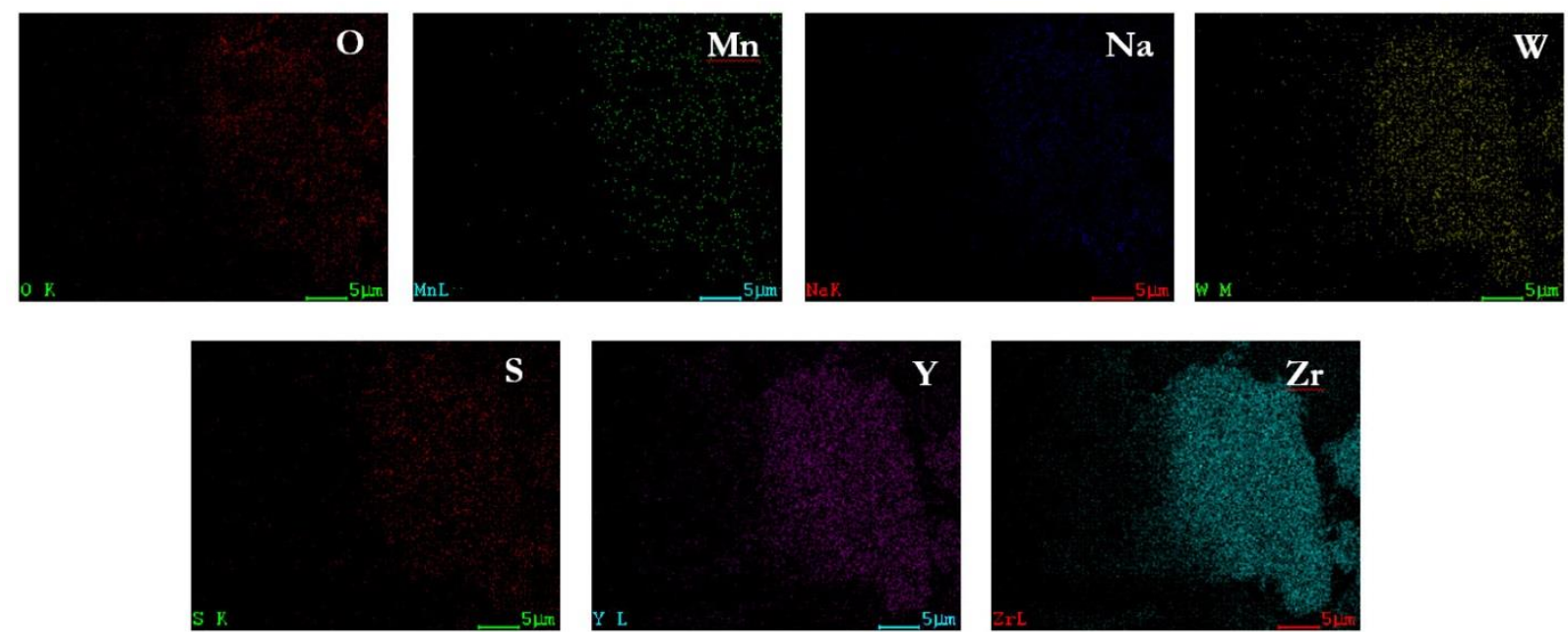

Fig. 6. The SEM-EDS mapping of elements on S-Na2 $\mathrm{WO}_{4}-\mathrm{Mn} / \mathrm{YSZ}$ catalyst.
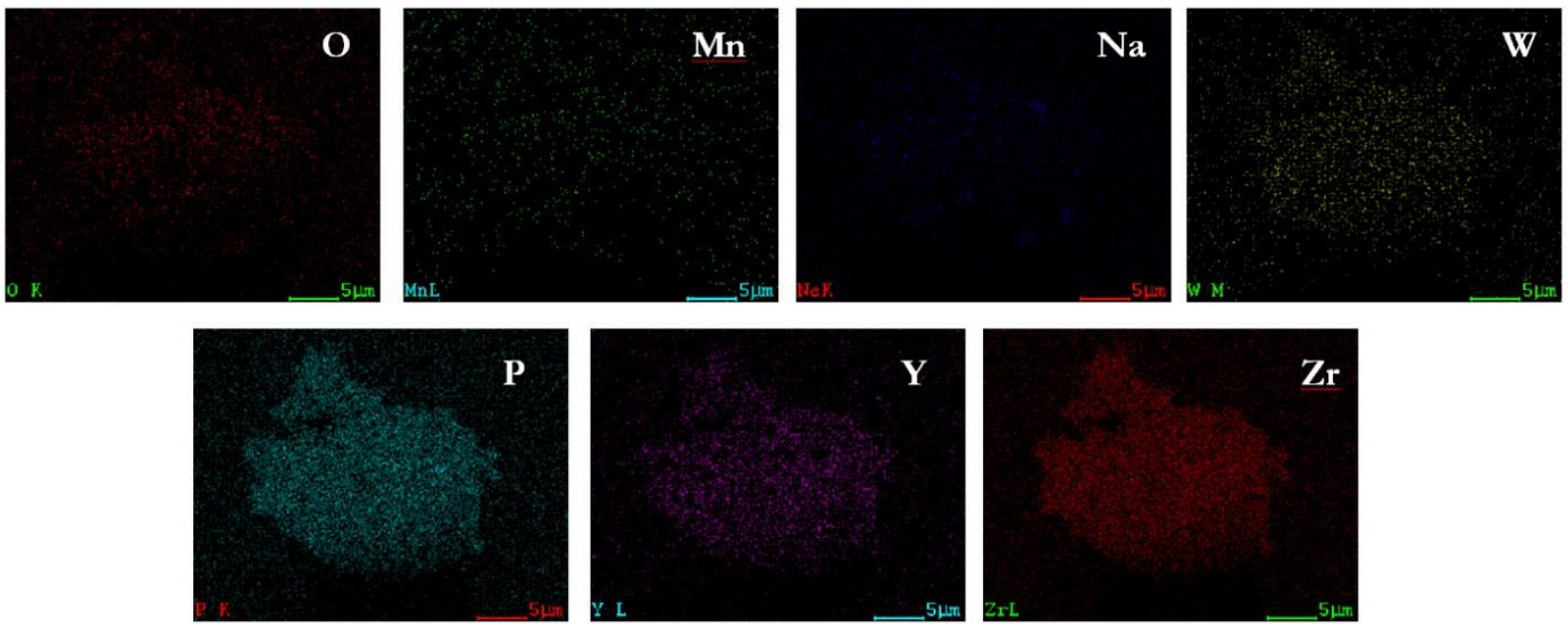

Fig. 7. The SEM-EDS mapping of elements on $\mathrm{P}_{-} \mathrm{Na}_{2} \mathrm{WO}_{4}-\mathrm{Mn} / \mathrm{YSZ}$ catalyst.
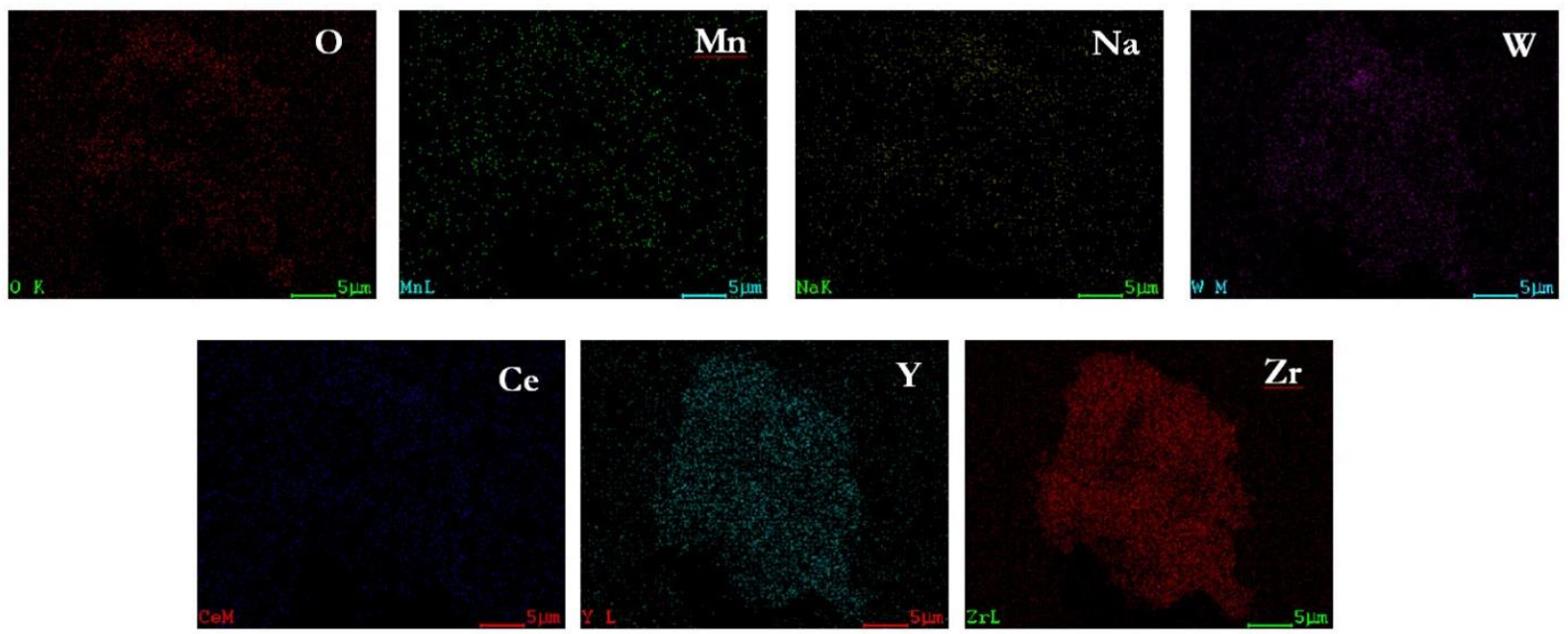

Fig. 8. The SEM-EDS mapping of elements on $\mathrm{Ce}-\mathrm{Na}_{2} \mathrm{WO}_{4}-\mathrm{Mn} / \mathrm{YSZ}$ catalyst.

The surface area, total pore volume, average pore diameter of all supports and catalyst were analyzed by BET measurement. The BET surface area for the YSZ was $11.263 \mathrm{~m}^{2} \mathrm{~g}^{-1}$. After the YSZ supports were loaded with catalysts precursor, the BET surface area of the catalyst decreased because active catalyst 
deposit in YSZ support [17]. Table 1 shows the BET surface area, total pore volume and average pore each catalyst.

Table 1. The results of BET surface area, total pore volume and average pore diameter of YSZ support catalyst.

\begin{tabular}{lccc}
\hline Catalyst & $\begin{array}{c}\text { BET } \\
\left(\mathbf{m}^{2} \mathbf{g}^{-1}\right)\end{array}$ & $\begin{array}{c}\text { Total pore volume } \\
\left(\mathbf{c m}^{\mathbf{3}} \mathbf{g}^{-\mathbf{1}} \mathbf{)}\right.\end{array}$ & Average pore diameter (nm) \\
\hline $\mathrm{YSZ}$ & 11.263 & 0.021 & 7.534 \\
$\mathrm{Na}_{2} \mathrm{WO}_{4}-\mathrm{Mn} / \mathrm{YSZ}$ & 7.483 & 0.015 & 7.875 \\
$\mathrm{~S}-\mathrm{Na}_{2} \mathrm{WO}_{4}-\mathrm{Mn} / \mathrm{YSZ}$ & 7.716 & 0.012 & 6.171 \\
$\mathrm{P}_{-} \mathrm{Na}_{2} \mathrm{WO}_{4}-\mathrm{Mn} / \mathrm{YSZ}$ & 5.789 & 0.009 & 6.628 \\
$\mathrm{Ce}-\mathrm{Na}_{2} \mathrm{WO}_{4}-\mathrm{Mn} / \mathrm{YSZ}$ & 6.954 & 0.009 & 5.566 \\
\hline
\end{tabular}

\subsection{Performance of Catalyst for OCM Reaction in Fixed Bed Reactor}

YSZ support showed the performance of OCM reaction, which provided methane conversion between 26.8-29.8\% and $\mathrm{C}_{2}$ selectivity between 17.1-29.7\%. The YSZ support exhibited the higher methane conversion when compared with other supports. When a $\mathrm{Na}_{2} \mathrm{WO}_{4}-\mathrm{Mn}$ was added to YSZ support, the catalyst was higher $C_{2}$ selectivity than YSZ support, which showed $27.5-52.1 \%$. for the $C_{2}$ selectivity. However methane conversion was lower than YSZ support. The S- $\mathrm{Na}_{2} \mathrm{WO}_{4}-\mathrm{Mn} / \mathrm{YSZ}$ and $\mathrm{P}-\mathrm{Na}_{2} \mathrm{WO}_{4}$ $\mathrm{Mn} / \mathrm{YSZ}$ showed the high performance in OCM reaction. The maximum $\mathrm{C}_{2}$ yield from $\mathrm{P}_{-} \mathrm{Na}_{2} \mathrm{WO}_{4}-\mathrm{Mn}$ /YSZ was $20.3 \%$ at $1073 \mathrm{~K}$ whereas S-Na2 $\mathrm{WO}_{4}-\mathrm{Mn} / \mathrm{YSZ}$ catalyst did not differ from $\mathrm{P}-\mathrm{Na}_{2} \mathrm{WO}_{4}-\mathrm{Mn}$ /YSZ, which provided $18.7 \% \mathrm{C}_{2}$ yield at $1073 \mathrm{~K}$. The sulfur helped the active phase such as $\mathrm{Na}_{2} \mathrm{SO}_{4}$ occurred and phosphorus can help manganese to form $\mathrm{Mn}_{2} \mathrm{O}_{3}$ which was the active phase. In case of cerium doped into $\mathrm{Na}_{2} \mathrm{WO}_{4} \mathrm{Mn} / \mathrm{YSZ}$ observed the decreasing of methane conversion and $\mathrm{C}_{2}$ selectivity when compared with $\mathrm{Na}_{2} \mathrm{WO}_{4}-\mathrm{Mn} / \mathrm{YSZ}$, as shown in Figs. 9-11.

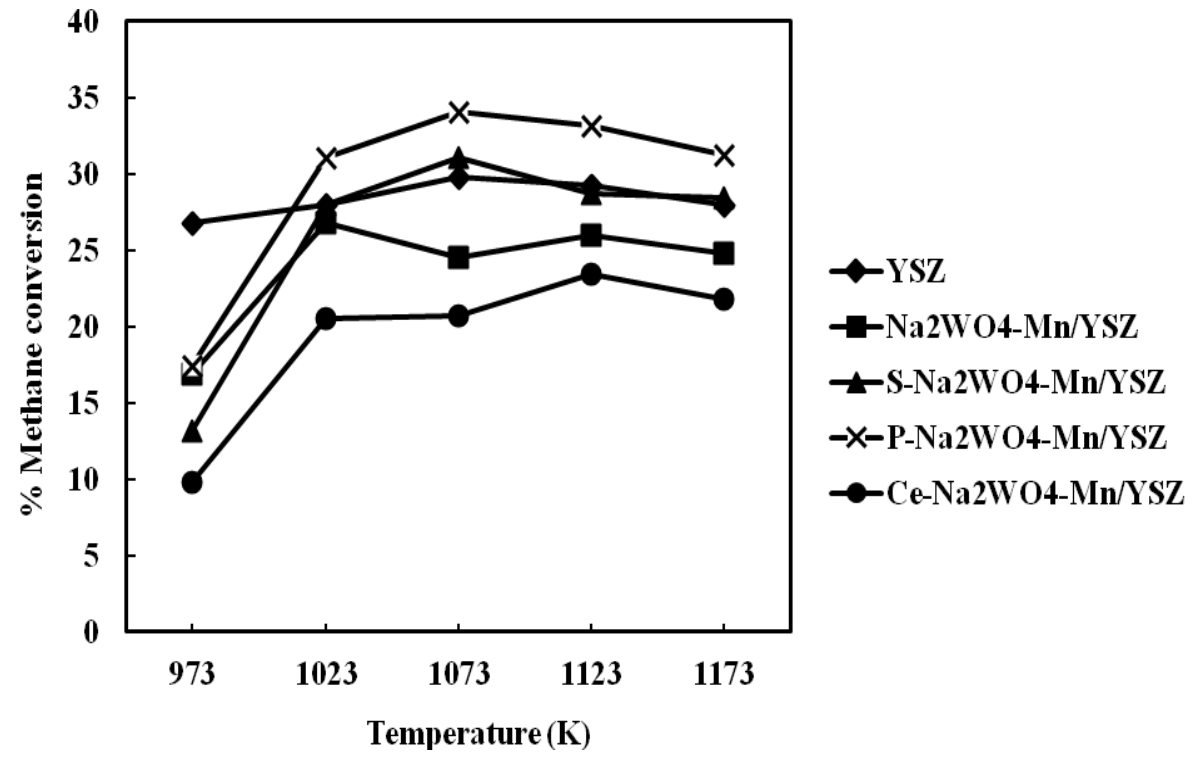

Fig 9. Methane conversion of YSZ support catalyst with WHSV $15,000 \mathrm{~cm}^{3} \cdot \mathrm{g}^{-1} \cdot \mathrm{h}^{-1}$. 


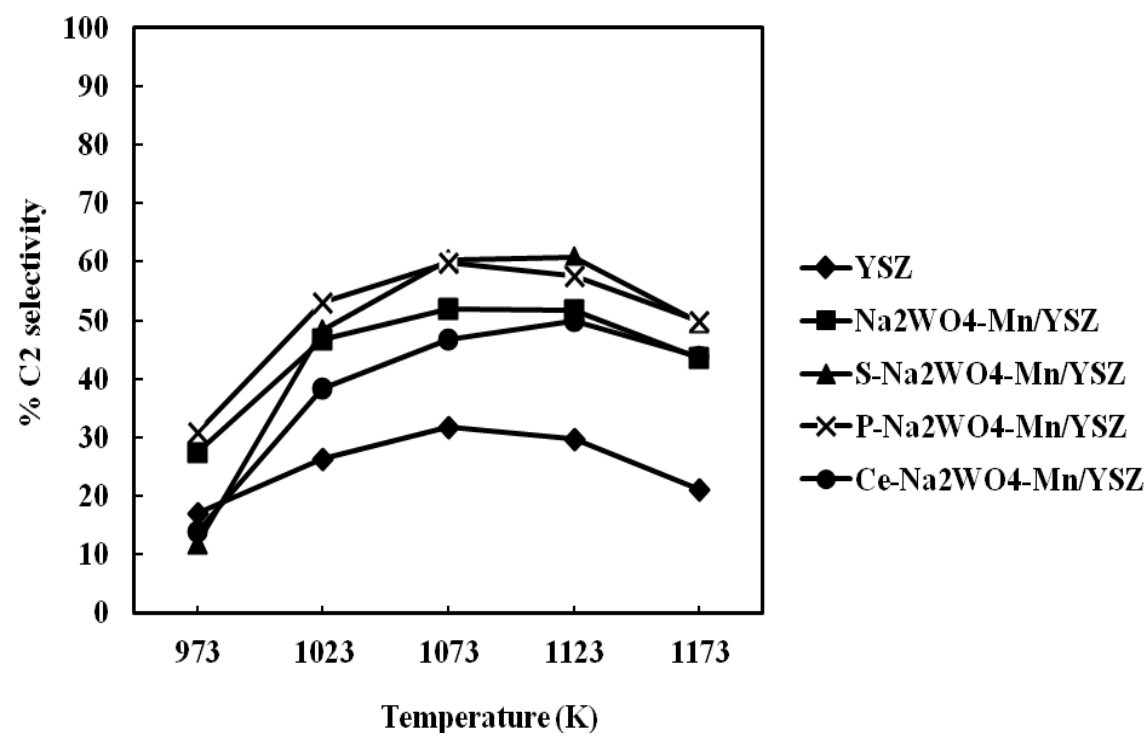

Fig. 10. $C_{2}$ selectivity of YSZ support catalyst with WHSV $15,000 \mathrm{~cm}^{3} \cdot \mathrm{g}^{-1} \cdot \mathrm{h}^{-1}$.

\subsection{OCM in SOFC Reactor for $\mathrm{C}_{2} \mathrm{H}_{4}$ Hydrocarbon and Electricity Co-generation}

After experiment in fixed bed reactor the P- $\mathrm{Na}_{2} \mathrm{WO}_{4}-\mathrm{Mn} / \mathrm{YSZ}$ was selected to test in SOFC reactor for investigate the performance to produce $\mathrm{C}_{2}$ hydrocarbon and electrical current. In addition, the stability of catalyst is interesting in this work, which chooses the best condition to carry out. The performance of catalysts and electrical current showed in Fig. 12 and Table 2 respectively. The highest $\mathrm{C}_{2} \mathrm{H}_{4}$ selectivity was approximately $91.2 \%$ at $1123 \mathrm{~K}$ and could be operated in temperature range between $973-1123 \mathrm{~K}$ whereas the $\mathrm{C}_{2} \mathrm{H}_{4}$ selectivity did not decreases. The maximum $\mathrm{C}_{2}$ yield was $10.5 \%$ and provided maximum power density about $9.8 \mathrm{~W} / \mathrm{m}^{2}$ at $1123 \mathrm{~K}$. The maximum power density was $16.8 \mathrm{~W} / \mathrm{m}^{2}$ at $1273 \mathrm{~K}$ and the voltage was similar others. In case OCM in SOFC reactor for $\mathrm{C}_{2} \mathrm{H}_{4}$ hydrocarbon and electricity co-generation have a few reports, Tagawa, et. al. [18] used $\mathrm{La}_{1.8} \mathrm{Al}_{0.2} \mathrm{O}_{3}$ as the anode catalyst with a plate-type Yttria Stabilized Zirconia (YSZ) as a solid electrolyte and $\mathrm{La}_{0.85} \mathrm{Sr}_{0.15} \mathrm{MnO}_{3}$ as a cathode the experiment provided $4.0 \%$ methane conversion and $96 \% \mathrm{C}_{2}$ selectivity. The electrical current and voltage were $10.1 \mathrm{~mA}$ and $0.96 \mathrm{~V}$, respectively or power densities was estimated $13.85 \mathrm{~W} / \mathrm{m}^{2}$. After that they carried out in SOFC cogeneration, which used the same anode and cathode catalyst but using the YSZ tube was electrolyte. It was high effective area the experiment result showed higher methane conversion about $13 \%$ and $15 \% \mathrm{C}_{2}$ yield at $1223 \mathrm{~K}$ then provided power density about $13.37 \mathrm{~W} / \mathrm{m}^{2}$. In addition, Lapeña-Rey and Middleton [19] investigated in $\mathrm{Na}_{2} \mathrm{WO}_{4}-\mathrm{Mn} / \mathrm{SiO}_{2}$ and $\mathrm{K}_{2} \mathrm{WO}_{4}-\mathrm{Mn} / \mathrm{SiO}_{2}$ in co-feed mode and electrochemical mode at $1123 \mathrm{~K}$. It found that the best performance was $86 \% \mathrm{C}_{2}$ selectivity, and $4 \% \mathrm{C} 2$ yield obtained from potassium tungstate supported catalysts in electrochemical mode. In case of the $\mathrm{Na}_{2} \mathrm{WO}_{4}-\mathrm{Mn} / \mathrm{SiO}_{2}$ catalyst from this literature provided lower $\mathrm{C}_{2}$ selectivity $(70.5-87.6 \%)$ than the $\mathrm{P}-\mathrm{Na} 2 \mathrm{WO} 4-\mathrm{Mn} / \mathrm{YSZ}$ catalyst at $1123 \mathrm{~K}$. 


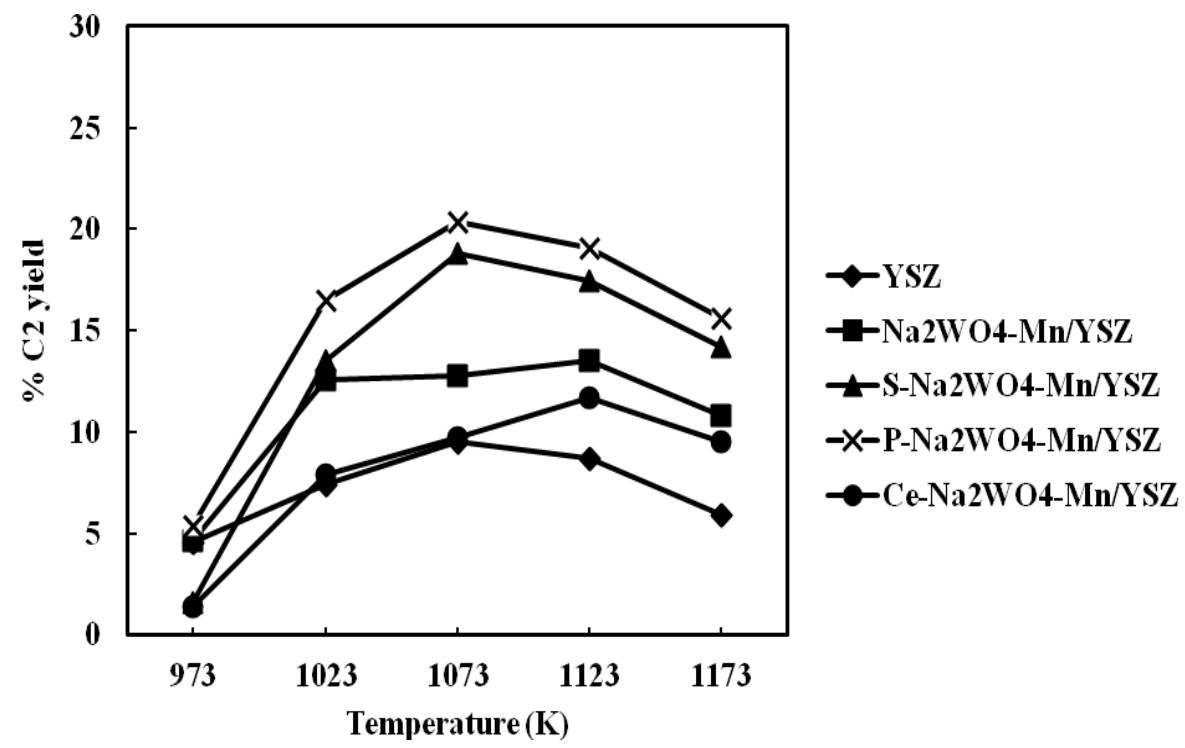

Fig. 11. $C_{2}$ yield of YSZ support catalyst with WHSV $15,000 \mathrm{~cm}^{3} \cdot \mathrm{g}^{-1} \cdot \mathrm{h}^{-1}$

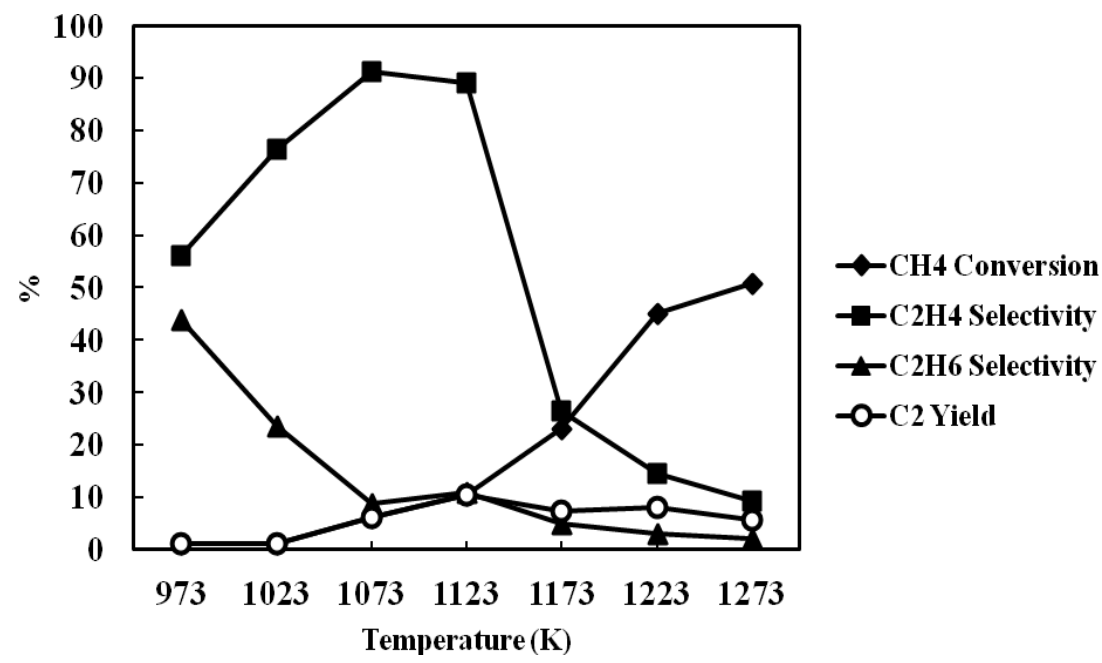

Fig 12. Performance of $\mathrm{P}-\mathrm{Na}_{2} \mathrm{WO}_{4}-\mathrm{Mn} / \mathrm{YSZ}$ catalyst in SOFC reactor.

Table 2. The electric power at each temperature for $\mathrm{P}-\mathrm{Na}_{2} \mathrm{WO}_{4}-\mathrm{Mn} / \mathrm{YSZ}$ catalyst in SOFC reactor.

\begin{tabular}{ccc}
\hline Temperature (K) & Current $(\mathbf{m A})$ & $\begin{array}{c}\text { Oxygen } \\
\text { consumption } \\
\left(\mathbf{m o l}^{-1} \mathbf{)}\right.\end{array}$ \\
\hline 973 & 12.00 & $1.68 \mathrm{E}-08$ \\
1023 & 17.50 & $1.74 \mathrm{E}-08$ \\
1073 & 35.00 & $3.40 \mathrm{E}-08$ \\
1123 & 75.00 & $5.14 \mathrm{E}-08$ \\
1173 & 95.00 & $1.69 \mathrm{E}-07$ \\
1223 & 145.00 & $2.09 \mathrm{E}-07$ \\
1273 & 185.00 & $3.39 \mathrm{E}-07$ \\
\hline
\end{tabular}




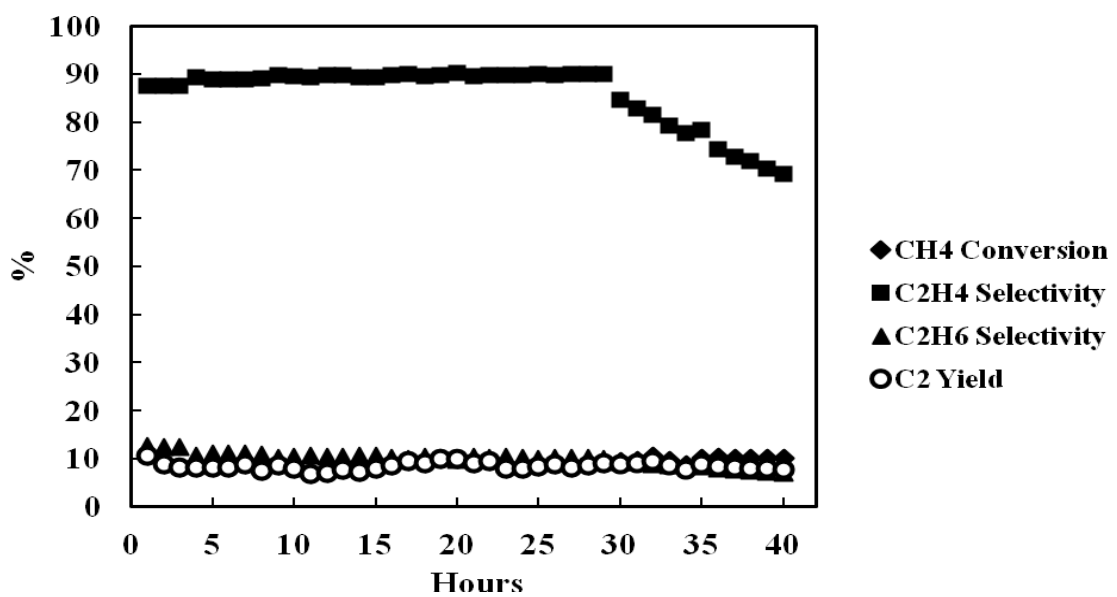

Fig. 13. Stability test of $\mathrm{P}-\mathrm{Na}_{2} \mathrm{WO}_{4}-\mathrm{Mn} / \mathrm{YSZ}$ catalyst in SOFC reactor at $1123 \mathrm{~K}$.

Moreover, the P-Na2WO4-Mn/YSZ catalyst showed the best performance in this work for SOFC reactor provided $10.5 \% \mathrm{C}_{2}$ yield which exhibited higher performance than Lapeña-Rey and Middleton [9]. In addition, the maximum $\mathrm{C}_{2}$ yield was obtained at $1123 \mathrm{~K}$, which lowers operating temperature than Kiatkittipong [20]. The report showed about 3\% $\mathrm{C}_{2}$ yield at $1173 \mathrm{~K}$. However, $\mathrm{C}_{2}$ yield were still low that caused the rate of oxygen permeates through YSZ membrane to form oxygen species did not match with methane consume oxygen species to produce methyl radical, which methyl radical coupling occurred to $\mathrm{C}_{2}$ product. When the oxygen permeated rate greater than rate of consume, The $\mathrm{O}_{2}$ - may be combined to form $\mathrm{O} 2$, which reaction with methane to form $\mathrm{CO}_{\mathrm{x}}$. If the oxygen permeate rate was lower than rate of consume occurred the low $\mathrm{C}_{2}$ yield. The other reason was the rate of oxygen permeates through YSZ membrane was low lead to methane cracking to generated carbon and hydrogen.

The P-Na2WO4-Mn/YSZ catalyst was examined in SOFC reactor. The catalyst exhibited the activity and stability at $1123 \mathrm{~K}$. The catalyst provided about $8.9 \%$ methane conversion and $8.0 \% \mathrm{C}_{2}$ yield. It showed the good performance for 29 hours (Fig. 13), after that the $\mathrm{C}_{2} \mathrm{H}_{4}$ selectivity decreased because occurred the carbon deposition on catalysts.

\section{Conclusion}

The P-Na2 $\mathrm{WO}_{4}-\mathrm{Mn} / \mathrm{YSZ}$ catalyst exhibited the high performance. The stability test exhibited very well because of more than $24 \mathrm{hr}$. Therefore, $\mathrm{P}-\mathrm{Na}_{2} \mathrm{WO}_{4}-\mathrm{Mn} / \mathrm{YSZ}$ catalyst was suitable and can be applied as anode material in solid oxide fuel cell (SOFC) reactor. However, power densities are still low due to the resistance of electrolyte. For the future work, the tape casting method will study in order to reduce the electrolyte thickness and prepare porous ceramic support for the electrode material. The electrode materials will be introduced into porous YSZ support by ion impregnation technique.

\section{Acknowledgements}

The authors gratefully acknowledge the Thailand Research Fund, Higher Education Commission and Chulalongkorn University for financial support, as well as Professor Piyasan Praserthdam.

\section{References}

[1] B. C. H. Steele, "Material science and engineering: The enabling technology for the commercialisation of fuel cell systems," J. Material. Sci, vol. 36, pp. 1053-1068, 2001.

[2] A. B. Stambouli and E. Traversa, "Solid oxide fuel cells (SOFCs): a Review of an Environmentally Clean and Efficient Source of Energy," J. Renew. and Sustainable Energ, vol. 6, pp. 433-455, 2002.

[3] C. G. Vayenas, S. Bebelis, and C. Kyriazis, "Solid electrolytes and catalysis. Part 1: Chemical cogeneration," Chemtech, vol. 21, pp. 422-428, 1991. 
[4] J. N. Michaels and C. G. Vayenas, "Styrene production from ethylbenzene on platinum in a zirconia electrochemical reactor," J. Electrochem. Soc., vol. 131, pp. 2544-2550, 1984.

[5] C. G. Vayenas and S. Neophytides, "Non-faradaic electrochemical modification of catalytic activity III: The case of methanol oxidation on Pt," J. Catalysis, vol. 127, pp. 645-664, 1991.

[6] R. D. Farr and C. G. Vayenas, "Production of nitric oxide from oxidation of ammonia," J. Electrochem. Soc., vol. 127, pp. 1478-1483, 1980.

[7] I. V. Yentekakis and C. G. Vayenas, "Chemical cogeneration in solid electrolyte cells," J. Electrochem. Soc., vol. 136, pp. 996-1002, 1989.

[8] N. Kiratzis and M. Stoukides, "The synthesis of hydrogen cyanide in a solid electrolyte fuel cell," J. Electrochem. Soc., vol. 134, pp. 1925-1929, 1987.

[9] A. S. Carrillo, T. Tagawa, and S. Goto, "Application of mist pyrolysis method to preparation of $\mathrm{Ni} / \mathrm{ZrO} 2$ anode catalyst for SOFC type reactor," Materials Research Bulletin, vol. 36, pp. 1017-1027, 2001.

[10] G. E. Keller and M. M. Bhasin, "Synthesis of ethylene via oxidative coupling of methane: I. Determination of active catalysts," Journal of Catalysis, vol. 73, pp. 9-19, 1982.

[11] F. Alcaide, P. L. Cabot, and E. Brillas, "Review Fuel cells for chemicals and energy cogeneration," Journal of Power Sources, vol. 153, pp. 47-60, 2006.

[12] J. H. White, E. A. Needham, R. L. Cook, and A.F. Sammells, "The electrochemical oxidative dimerization of methane," Solid State Ionics, vol. 53-56, pp. 149-161, 1992.

[13] T. Tagawa, K. K. Moe, M. Ito, and S. Goto, "Fuel cell type reactor for chemicals-energy cogeneration," Chemical Engineering Science, vol. 54, vol. 1553-1557, 1999.

[14] D. Wang, M. P. Rosynek, and J. H., Lunsford, "Oxidative Coupling of methane over oxide-supported sodium-manganese catalysts," Journal of Catalysis, vol. 155, pp. 390-402, 1995.

[15] $\mathrm{H}$. $\mathrm{Li}$ and J. Wang, "Study on $\mathrm{CO}_{2}$ reforming of methane to syngas over $\mathrm{Al}_{2} \mathrm{O}_{3}-\mathrm{ZrO}_{2}$ supported $\mathrm{Ni}$ catalysts prepared via a direct sol-gel process," Chemical Engineering Science, vol. 59, pp. 4861-4867, 2004.

[16] S. F. Ji, T. C. Xiao, S. B. Li, C. Z. Xu, R. L. Hou, K. S. Coleman, and M. L. Green, "The relationship between the structure and the performance of $\mathrm{Na}-\mathrm{W}-\mathrm{Mn} / \mathrm{SiO}_{2}$ catalysts for the oxidative coupling of methane," Applied Catalysis, vol. 225, pp. 271-284, 2002.

[17] Z. Gao and Y. Ma, "Direct oxidation of methyl radicals in OCM process deduced from correlation of product selectivities," Journal of Natural Gas Chemistry, vol. 19, pp. 534-538, 2010.

[18] T. Tagawa, K. K. Moe, T. Hiramatsu, and S. Goto, "Design of electrode for solid oxide fuel cells reactor," Solid State Ionics, vol. 106, pp. 227-235, 1998.

[19] N. Lapeña-Rey and P. H. Middleton, "The selective oxidation of methane to ethane and ethylene in a solid oxide electrolyte reactor," Applied Catalysis, vol. 240, pp. 207-222, 2003.

[20] W. Kiatkittipong, "Co-generation of $\mathrm{C}_{2}$ hydrocarbons and electric power from methane in a solid oxide fuel cell type reactor," Doctoral Dissertation, Department of Chemical Engineering, Faculty of Engineering, Chulalongkorn University, 2004. 
